October 2001 - NREL/CP-520-30983

\title{
Evaluation of $\mathrm{NF}_{3}$ versus Dimethylhydrazine as $\mathbf{N}$ Sources for GaAsN
}

\section{Preprint}

S. Kurtz, R. Reedy, B. Keyes, G. Barber, J. Geisz, D. Friedman, W. McMahon, J. Olson, C. Kramer, and $\mathrm{M}$. Young

To be presented at the NCPV Program Review Meeting Lakewood, Colorado

14-17 October 2001

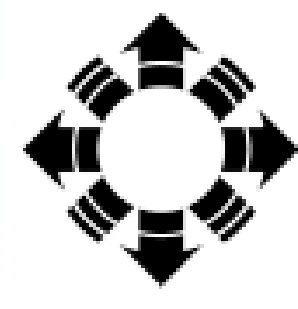

\section{NPEI}

National Renewable Energy Laboratory

1617 Cole Boulevard

Golden, Colorado 80401-3393

NREL is a U.S. Department of Energy Laboratory

Operated by Midwest Research Institute $\bullet$ Battelle $\bullet$ Bechtel

Contract No. DE-AC36-99-G010337 


\section{NOTICE}

The submitted manuscript has been offered by an employee of the Midwest Research Institute (MRI), a contractor of the US Government under Contract No. DE-AC36-99G010337. Accordingly, the US Government and MRI retain a nonexclusive royalty-free license to publish or reproduce the published form of this contribution, or allow others to do so, for US Government purposes.

This report was prepared as an account of work sponsored by an agency of the United States government. Neither the United States government nor any agency thereof, nor any of their employees, makes any warranty, express or implied, or assumes any legal liability or responsibility for the accuracy, completeness, or usefulness of any information, apparatus, product, or process disclosed, or represents that its use would not infringe privately owned rights. Reference herein to any specific commercial product, process, or service by trade name, trademark, manufacturer, or otherwise does not necessarily constitute or imply its endorsement, recommendation, or favoring by the United States government or any agency thereof. The views and opinions of authors expressed herein do not necessarily state or reflect those of the United States government or any agency thereof.

Available electronically at http://www.osti.gov/bridge

Available for a processing fee to U.S. Department of Energy and its contractors, in paper, from:

U.S. Department of Energy

Office of Scientific and Technical Information

P.O. Box 62

Oak Ridge, TN 37831-0062

phone: 865.576 .8401

fax: 865.576.5728

email: reports@adonis.osti.gov

Available for sale to the public, in paper, from:

U.S. Department of Commerce

National Technical Information Service

5285 Port Royal Road

Springfield, VA 22161

phone: 800.553 .6847

fax: 703.605.6900

email: orders@ntis.fedworld.gov

online ordering: http://www.ntis.gov/ordering.htm

Printed on paper containing at least $50 \%$ wastepaper, including $20 \%$ postconsumer waste 


\title{
Evaluation of $\mathbf{N F}_{3}$ versus Dimethylhydrazine as $\mathbf{N}$ sources for GaAsN
}

\author{
S. Kurtz, R. Reedy, B. Keyes, Greg Barber, J. Geisz, D. Friedman, W. McMahon, J. Olson, C. Kramer, and M. Young \\ National Renewable Energy Laboratory, 1617 Cole Boulevard, Golden, CO 80401, USA
}

\begin{abstract}
Hydrazine, $\mathrm{NF}_{3}$, dimethylhydrazine, trimethylgallium, and triethylgallium are studied for the growth of $\mathrm{GaAs}_{1-\mathrm{x}} \mathrm{N}_{\mathrm{x}}$ by metal-organic chemical-vapor deposition (MOCVD). $\mathrm{NF}_{3}$ is shown to incorporate nitrogen very much like hydrazine, both of which are more efficient nitrogen sources than di-methylhydrazine. The choice of gallium precursor (triethyl-gallium or trimethylgallium) also affects the nitrogen incor-poration. The growth rate of the GaAsN is decreased at low temperatures when trimethylgallium is used and at high temperatures when $\mathrm{NF}_{3}$ is used. The carbon and hydrogen impurity levels are relatively unaffected by changing nitro-gen precursors, but the use of triethylgallium decreases the carbon contamination. These lower carbon levels are not correlated with a significant change in the background hole concentration except for $\mathrm{x}<$ $0.2 \%$. The photoluminescence and Hall data for as-grown GaAsN are also unaffected by the choice of nitrogen precursor.
\end{abstract}

\section{Introduction}

Nitrogen-containing III-V alloys have attracted recent attention because a very small amount of nitrogen can lower the alloy's bandgap dramatically [1]. The growth of highquality (lattice-matched), low-bandgap alloys on GaAs is beneficial for long-wavelength lasers [1] and for multijunction solar cells $[2,3]$. However, GaAsN and GaInAsN are reported to have poor optoelectronic properties, an especially serious problem for solar cells $[2,3]$. Although the exact origin of the poor material quality is unknown, it is possible that carbon and hydrogen impurities degrade GaAsN material [4,5].

The growth of high-purity GaAsN by MOCVD might be achieved if appropriate precursors and growth conditions could be identified. The most common $\mathrm{N}$ source for MOCVD-grown GaAsN is unsymmetric dimethylhydrazine $(\mathrm{DMH})$, which contains both hydrogen and carbon. $\mathrm{NF}_{3}$ contains neither hydrogen nor carbon and might also provide an advantage because of improved $\mathrm{N}$-incorporation efficiency, source cleanliness, or hazard reduction.

This paper compares the incorporation of nitrogen using a variety of precursors. These results are presented in more detail elsewhere [6,7].

\section{Experimental Method}

The GaAsN epilayers were grown by atmospheric-pressure MOCVD on GaAs substrates. Arsine, TMGa, TEGa, trimethylindium, $\mathrm{DMH}$, hydrazine, and $\mathrm{NF}_{3}$ were used in a hydrogen carrier.

The rocking-mode, X-ray diffraction measurements used the (400) GaAs reflection of $\mathrm{Cu}$ radiation. The $\Delta \theta$ values are the difference between the Bragg angle of the GaAs substrate and that of the epilayer. The nitrogen content of
$\operatorname{GaAs}_{1-\mathrm{x}} \mathrm{N}_{\mathrm{x}}$ was estimated from $\mathrm{x}=2 \times 10^{-5} \Delta \theta(\operatorname{arc} \mathrm{sec})$, which assumes that the epilayers are coherently strained [8]. Data supporting the validity of this assumption are presented below, and even if there is some relaxation, the primary conclusions would not change. The experimental techniques are described in detail elsewhere [6,7].

\section{Results}

The addition of nitrogen to GaAs is known to reduce both the bandgap and the lattice constant [6,7]. The incorporation efficiency of nitrogen in GaAs by MOCVD is low. However, nitrogen incorporates much more efficiently from $\mathrm{NF}_{3}$ than from $\mathrm{DMH}$, as seen in Fig. 1. Hydrazine showed much higher incorporation than DMH [8], but appears very similar to $\mathrm{NF}_{3}$. The almost vertical line at the left side of Fig. 1 shows the data expected if the N/As ratio in the film were the same as in the gas phase, demonstrating how inefficient the incorporation is for all of the sources.

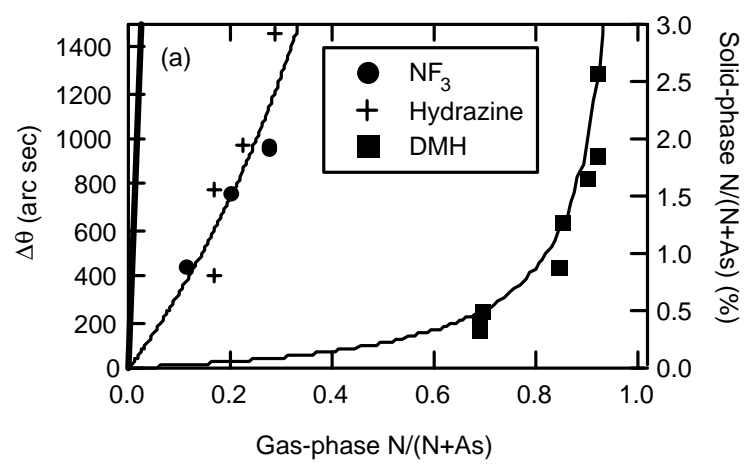

Fig. 1. The incorporation of nitrogen relative to the gas-phase group $\mathrm{V}$ concentration by varying the nitrogen. The bold (almost vertical) line at the left shows the relationship of solid-state N/V = gas-phase N/V. These runs used a constant growth temperature of $550^{\circ} \mathrm{C}$ and $\mathrm{TMGa}$.

For all combinations of precursors shown in Fig. 2, the nitrogen incorporation decreased with increasing growth temperature. At $700^{\circ} \mathrm{C}$, all the data sets showed negligible nitrogen incorporation. This trend is consistent with other reports in the literature [4,9]. The observed growth rate is shown as a function of growth temperature in Fig. 3.

At low growth temperatures, the observed growth rate is significantly decreased when TMGa is used. At high growth temperatures, the growth rate decreases when $\mathrm{NF}_{3}$ is used, possibly because of the formation of gallium fluorides. The hole concentrations are reduced for growth at high temperature regardless of $\mathrm{N}$ precursor, as seen in Fig. 4. Data for GaAs are included for reference.

Carbon contamination can explain much of the observed hole concentration, but not all. Fig. 5 shows how using TEGa reduces [C], but has little effect on the hole 
concentration. The reduction is more apparent when $\mathrm{NF}_{3}$ and TEGa are used together.

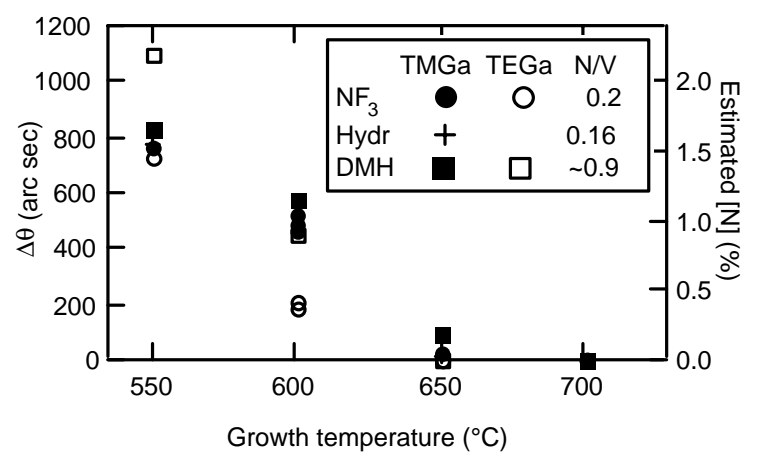

Fig. 2. The incorporation of nitrogen as a function of the growth temperature for three nitrogen and two gallium precursors. The growth rate was intended to be $4 \mu \mathrm{m} / \mathrm{h}$. The samples grown with DMH and TMGa used a N/V of 0.9 , whereas the DMH and TEGa samples used a N/V of 0.85 .

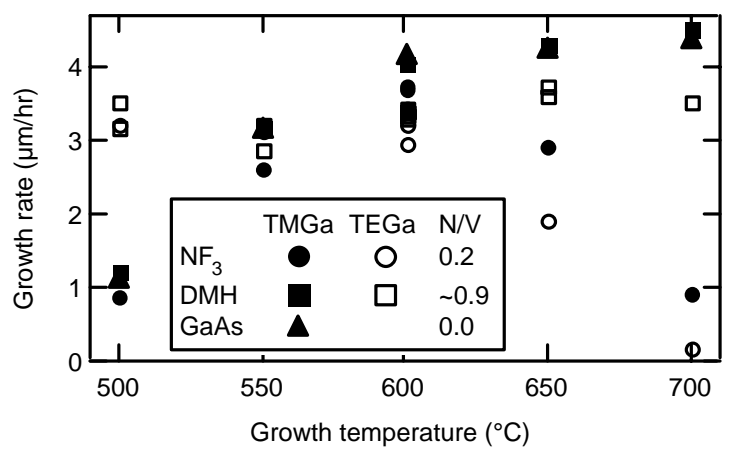

Fig. 3. The measured growth rate as a function of growth temperature (same samples as described by Fig. 2). The Ga flux was held constant.

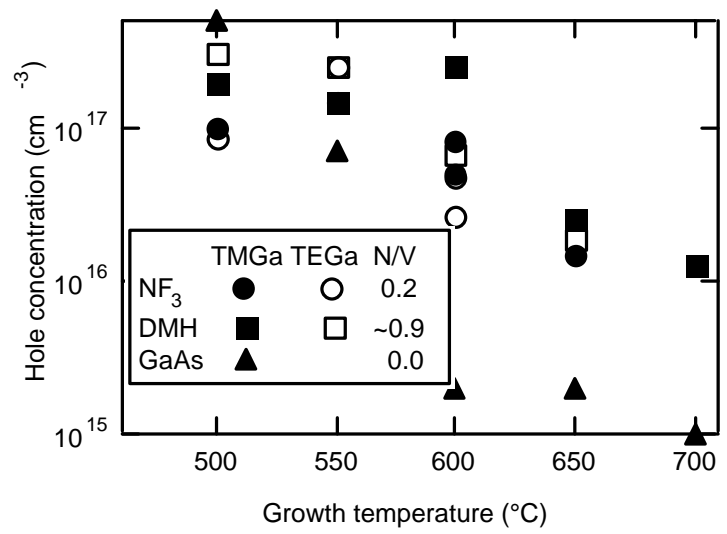

Fig. 4. The background hole concentration for GaAsN and GaAs samples. The intended growth rate was $4 \mu \mathrm{m} / \mathrm{h}$. The samples grown with $\mathrm{DMH}$ and TMGa used a N/V of 0.9 , whereas the DMH and TEGa samples used a $\mathrm{N} / \mathrm{V}$ of 0.85 . The arsine partial pressure was $\sim 0.2$ torr.

The use of $\mathrm{NF}_{3}$ does not significantly reduce the hydrogen contamination of the GaAsN. Fig. 6 shows the hydrogen concentration as a function of the nitrogen level. The lack of hydrogen in $\mathrm{NF}_{3}$ had led to the hope that the hydrogen could be reduced through its use. The results show that the hydrogen is coming from another source, such as the hydrogen carrier or the arsine. A separate growth was completed with primarily $\mathrm{N}_{2}$ carrier, but the hydrogen level was not reduced, implying that the arsine is the most likely source of the hydrogen contamination.

The minority-carrier lifetimes and majority-carrier mobilities were studied [6,7]. The [N] affects the lifetime, but the choice of nitrogen precursor does not. The hole mobility is also unaffected by the nitrogen precursor.

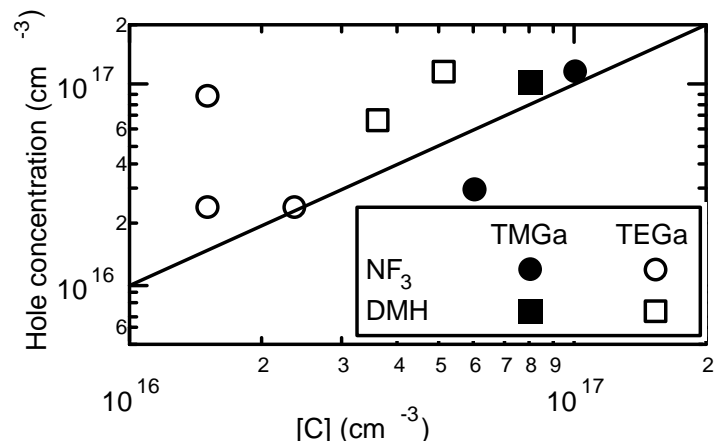

Fig. 5. Comparison of the carbon and hole concentrations. The line indicates the equality of the two.

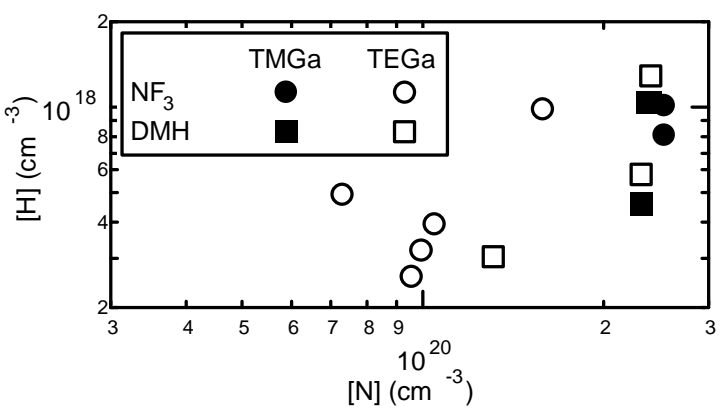

Fig. 6. $[\mathrm{H}]$ as a function of $[\mathrm{N}]$, both measured by SIMS for a subset of the samples described above.

\section{Acknowledgments}

We thank A. Ptak for useful discussions. This work was completed at the National Renewable Energy Laboratory under DOE Contract no. DE-AC36-99GO10337.

\section{References}

[1] M. Kondow, K. Uomi, A. Niwa, T. Kitatani, S. Watahiki, and Y. Yazawa, Jpn. J. Appl. Phys. 35 (1996) 1273-1275.

[2] S. R. Kurtz, A. Allerman, E. Jones, J. Gee, J. Banas, and B. Hammons, Appl. Phys. Lett. 74 (1999) 729.

[3] D. J. Friedman, J. Geisz, S. Kurtz, and J. Olson, J. Cryst. Growth 195 (1998) 409-415.

[4] A. Moto, M. Takahashi, and S. Takagishi, J. Cryst. Growth 221 (2000) 485-490.

[5] J. C. Zolper, M. Sherwin, A. Baca, and R. Schneider, J Electron Mater 24 (1995) 21.

[6] S. Kurtz et al., accepted J. Cryst. Growth (2001).

[7] S. Kurtz et al., accepted J. Cryst. Growth (2001).

[8] D. J. Friedman, A. Norman, J. Geisz, and S. Kurtz, J. Cryst. Growth 208 (2000) 11.

[9] C. Jin, Y. Qiu, A. Nikishin, and H. Temkin, Appl. Phys. Lett. 74 (1999) 3516. 